\title{
Change in total anti-oxidant capacity (TAC) of tissue, a new method for improving dermal wound healing
}

\author{
Banimohammad $M^{1}$, Ravaei $\mathbf{H}^{1}$, Khalafi $\mathrm{P}^{2}$, Javdan $\mathrm{G}^{3,4}$, Ayatollahi $\mathrm{SA}^{5,6}$, Davoodi $\mathrm{SH}^{7,8}$ \\ 1. Medical Student, Physiology Research Center, Faculty of Medicine, Iran University of Medical Sciences, Tehran, Iran. \\ ORCID ID:- \\ 2. Medical Student, School of Medicine, Tehran University of Medical Sciences, Tehran, Iran. \\ 3. Assistant Professor of Nutrition Sciences, Minimally Invasive Surgery Research Center, Iran University of Medical \\ Sciences, Tehran, Iran. \\ 4. Assistant Professor of Nutrition Sciences, Physiology Research Center, Faculty of Medicine, Iran University of Medical \\ Sciences, Tehran, Iran. \\ 5. Professor of Pharmacognosy, Phytochemical Research Center, Shahid Beheshti University of Medical Sciences, Tehran, \\ Iran. \\ 6. Professor of Pharmacognosy, School of Pharmacy, Shahid Beheshti University of Medical Sciences, Tehran, Iran. \\ 7. Associate Professor of Nutrition Sciences, Cancer Research Center, Shahid Beheshti University of Medical Sciences, \\ Tehran, Iran. \\ 8. Associate Professor of Nutrition Sciences, Department of Basic Sciences and Cellular and Molecular Nutrition, Faculty of \\ Nutrition Sciences and Food Technology and National Nutrition and Food Technology Research Institute, Shahid Beheshti \\ University of Medical Sciences, Tehran, Iran (Corresponding Author), Tel: +98-2122360660, Email: \\ hdavoodi1345@gmail.com. ORCID ID: 0000-0001-7834-1911
}

\begin{abstract}
Background and Aim: Total antioxidant capacity (TAC) of the tissue is an important factor in determining the physiological or physio-pathological function of oxygen reactive spices. Release of reactive oxygen species (ROS) in dermal wounds, leads to necrosis as well as apoptosis and tissue loss. Management of the risk factors for tissue loss due to flap failure can reduce risk factors with resultant improvement in the survival and efficacy of the flaps.
\end{abstract}

Materials and Methods: 40 Sprauge-Dawkey rats were divided into 4 groups (1) sham group with an $8 \times 3 \mathrm{~cm}$ skin cut without skin elevation (2) Flap group with an $8 \times 3 \mathrm{~cm}$ skin cut with skin elevation (3) cymophenol group treated with cymophenol (25 mg/kg/day) (4) cymophenol group treated with cymophenol $(50 \mathrm{mg} / \mathrm{kg} /$ day $)$ after surgery. After one week, percentage of the living tissue, superoxide dismutase (SOD) activity and amount of malondialdehyde (MDA) were measured in the groups and the proximity results were extracted. Using GraphPad Prism 6 software, data were analyzed and compared by ANOVA and Tukey test.

Results: Cymophenol application decreased the amount of malondialdehyde $(p<0.05)$, increased superoxide dismutase activity $(p<0.01)$, led to reduced oxidative stress in the flap tissues and increased resistance capacity against oxidative stress. Also we found improved survival rate of the flaps $(\mathrm{p}<0.05)$.

Conclusion: This study revealed the protective effect of cymophenol against oxidative stress and on survival of the flaps. However, more studies are required to determine its benefits in clinical use.

Keywords: Total antioxidant capacity, Wound healing, Oxidative stress, Cymophenol Received: March 16, 2019

Accepted: May 5, 2019

\footnotetext{
How to cite the article: Banimohammad M, Ravaei H, Khalafi P, Javdan G, Ayatollahi SA, Davoodi SH. Comparison between the effects of group-based acceptance and commitment therapy and group-based reality therapy on work-family conflict \& psychological well-being of married female staffs. SJKU 2019; 24(3): 96109.
} 


\section{تغيير ظرفيت كلى آنتىاكسيدافى بافت (TAC)}

\section{روش نوين ارتقاء ترميم زخم هاى بوستى}

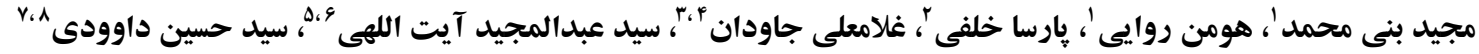

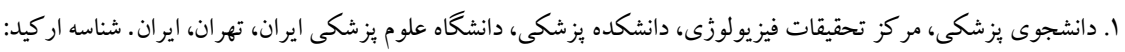

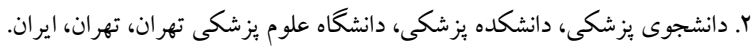

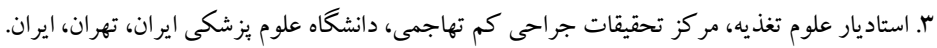

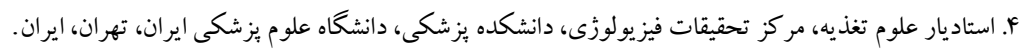

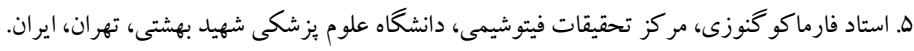

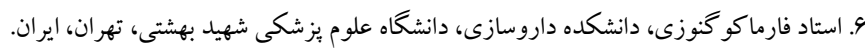

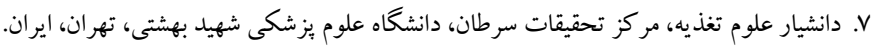

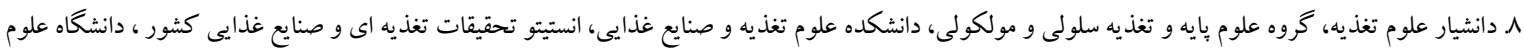

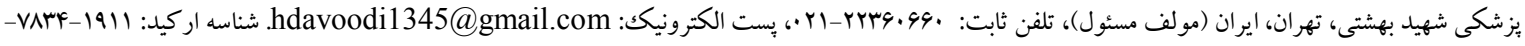

جكيده زمينه و هدف: ظرفيت كلى آنتىاكسيدانى بافت، عامل مهمى در تعيين عملكرد فيزيولوزيك يا فيزيوياتولوزيك گونههاى

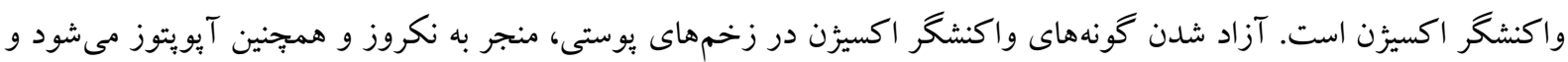

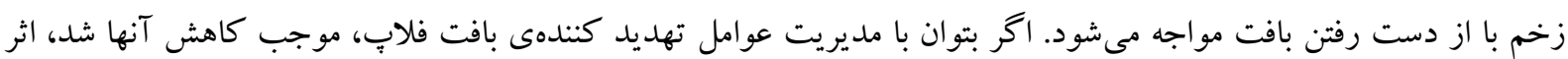

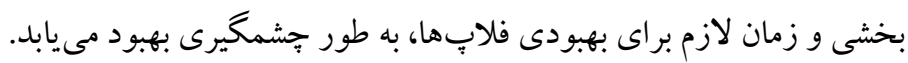

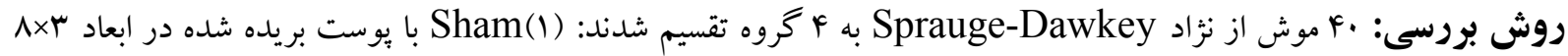

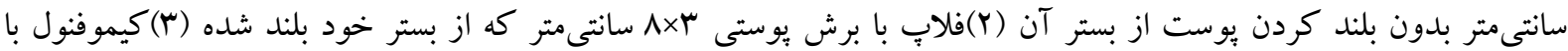

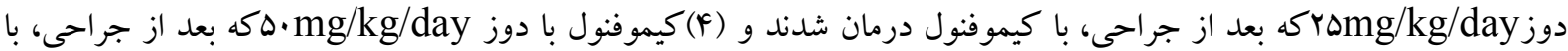
كيموفنول درمان شدند. يكك هفته بعد، درصد بافت سالم مانده، SOD و MDA اندازه گيرى شده و همجنين ميزان نزديكى نتايج، استخراج شد. تحليلها با استفاده از نرم افزار GraphPad Prism 6 انجام شد. تجزيه و تحليل واريانس (Tukey test) براى مقايسه دادههاى بيوشيميايى بين خروهها انجام شد. (ANOVA)

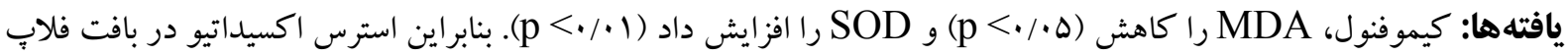
به ميزان قابل توجهى كاهش و ظرفيت مقابله با آن افزايش ييدا كرده است. ميزان بقاى فلاب يوستى نيز افزايش يافت (ه •/•> p). نتيجه كيرى: در نهايت يزوهش حاضر، اثر محافظتى كيموفنول بر مديريت استرس اكسيداتيو و سالم مانى بافت فلاب راب را آشكار

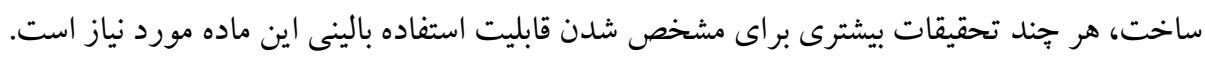
وازه كان كليدى: ظرفيت كلى آنتى اكسيدانى، ترميم زخم، استرس اكسيداتيو، كيموفنول

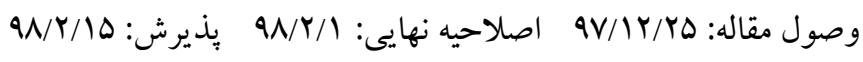


مىباشد. با كاهش Bax يـا افزايش BCL-2، بقـاى بافت

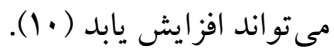

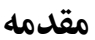

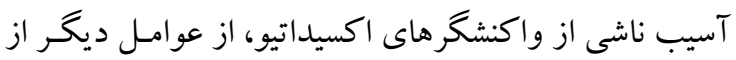

فلابهاى بوستى در اعمال جراحى مختلف به خاطر سادگى

دست رفتن بافت مىباشد. آزار اكسيداتيو مىتواند به استرس در تكنيكك و همخوانى با ساير بافتها، براى ترميم ضايعات

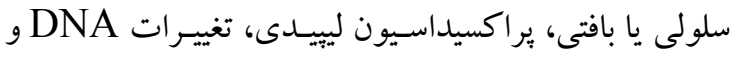

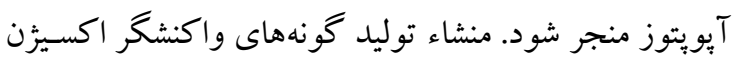

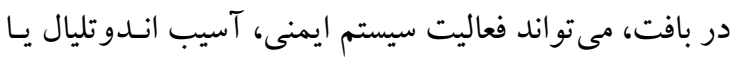

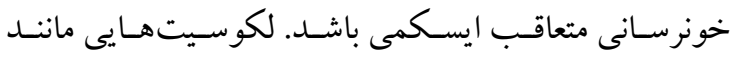

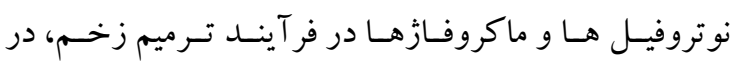
برهمكنش با سلولهاى آسيب ديده يا ميكروب هـاى مهاجم

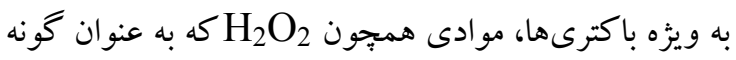

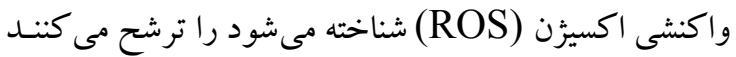

مطالعـات متعـددى بــراى ارزيـابى تـأثير اسـتفاده از عوامـل مختلف درمانى بر بديـدهــاى ايسكمى -ريرفيوزن (IR)

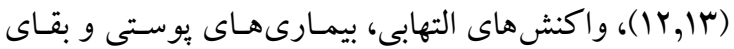

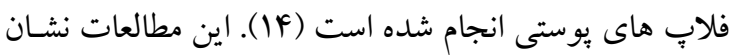
داده اند كه با كـاهش ميزان آزار اكسيداتيو، هـم از ميزان نكروز بافتى و آسيب مستقيم سلولى كاسته مسى شـود و هـم ميزان آبويتوز و مدياتور هاى بيش برنـدهى آيويتوز كاسته مىشود. بنابر اين با مديريت ميزان ROS در بافت، مسىتوان

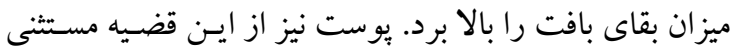
نيست و اكر بتوان راهى براى كاهش آزار اكسيداتيو متعاقب جراحى فلاب يافت، از دست رفتن بافت (Tissue loss)

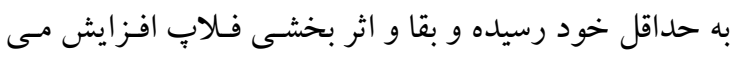
يابد.ROS مى تو اند باعث تقويت ترشح سيتو كين هاى موثر در التهـاب (10) و القـاى مـاتريكس متالويروتئينازهـا شود همجنِين ROS و RNS (MMPs) مى تواند به طور مستقيم يا غير مستقيم (از طريق فعال سـازى

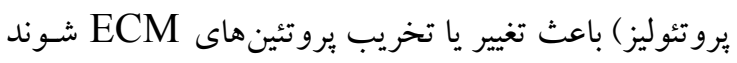

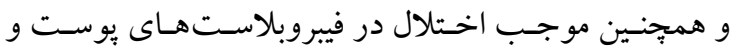

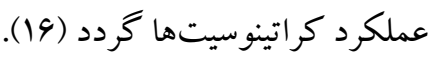

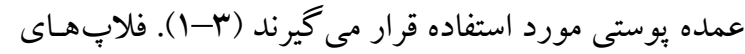
يوستى مى توانند بر اساس منبع خون، محل قرار كيرى آنها در ارتباط با بستر گيرنده يا تر كيب بافت، طبقه بندى شـوند. فلإِهاى يوستى برداشته شده از ناحيه پِا و بافـتهـاى آزاد

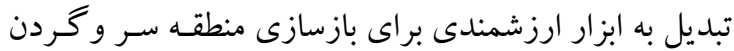

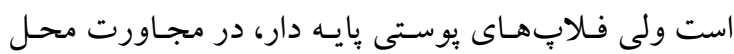
آسيب بوستى، روش بسـيار مفيـدى بـراى بهترين درمـانهـا بقاى فلاب يوستى و اثربخشى آن بـا مسـائلى جـدى مواجـهـ هستند و هنوز در معـرض خطرات زيـان بـارى قرار دارنـد.

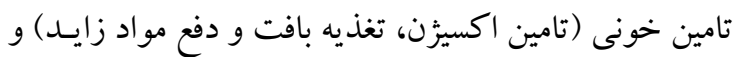

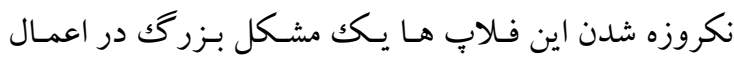

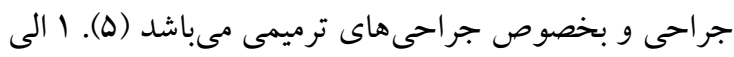

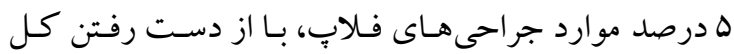

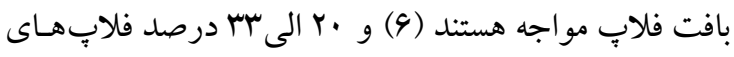

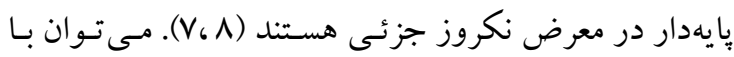

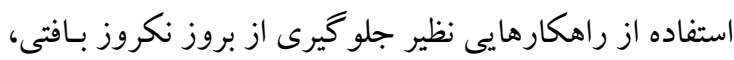

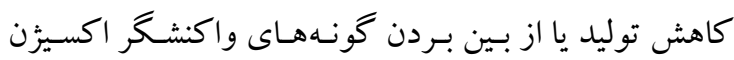

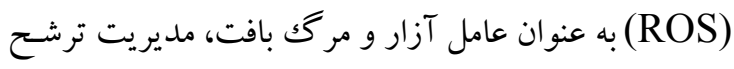
واسطههاى التهابى، افزايش ظرفيت آنتى اكسيدانى موجود در

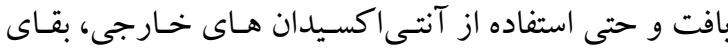
فلابِهاى يوستى را افزايش داد. عـلاوه بـر نكروز بـافتى، آيويتوز نيز به عنوان يكك آسـيب، رونــد بسيار مهمى در از دست رفتن بافت است. واسطه هاى متعددى مسير آيويتوز را تنظيم مى كنتـد همجِون BCL-2 و Bax كـه از مهمترين تنظيم كنندهاى آيويتوز هستند (9). BCL-2 دو بروتئين مهـم از خـانواده BCL-2

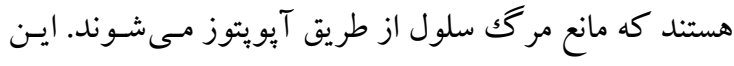

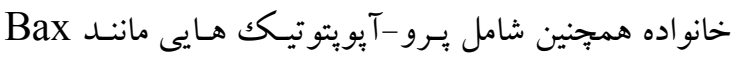


اكسيدان در تشخيص و درمان يِشرفته ى ايسكمى -ريرفيـون مــوثر بــوده اســت (FF). در مطالعـهاى كــه روى اثــــات كيموفنول بر روى ايسكمى -ريرفيون (IR) مغز انجـام شـد ، نتايج نشان داد كه ييش -درمان بـا كيموفنول سـبب كـاهش

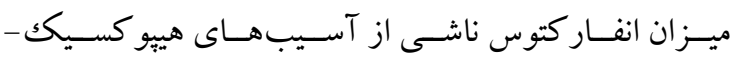
ايسكميكك، محافظت از بافت مغزى در مقابـل آبويتوز در مريو شــرايط ايسـكمى -ريرفيـوزن، محافظـت از نــورون هــا در بر ابر تخريب توسط اكسيزن، محروميت كلـو كز (كسه موجـب آسيب سلول مى شود)، افزايش نسبت يـروتئين هـاى Bcl-2

به Bax و كاهش شكستن Caspase-3 مى شود (Fه). تاكنون مطالعهاى روى تاثيرات كيموفنول بـر ميـزان اسـترس اكسيداتيو و نكروز بافت فلاٍ انجام نشده است. مـا در ايسن آزمايش اثر درمان با كيموفنـول را بـراى اولـين بـار بـر روى ميز ان بقاى فلاٍٍ بوستى سنجيديم.

\section{روش بررسى نمونه تيرى}

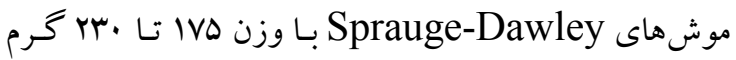
در اين مطالعه استفاده شـدند. ·F مـوش صـحرايى بـه جهـار

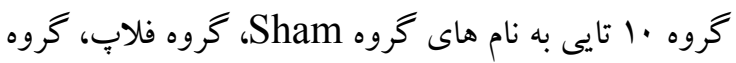
كيموفنـول بـا دوز romg/kg/day، و خروه كيموفنسول بـا

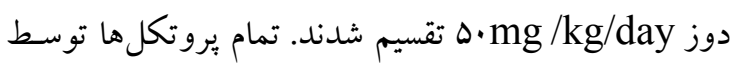

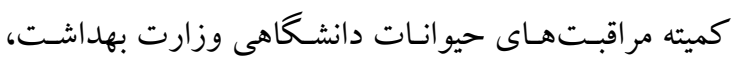
درمان و آموزش يزشكى تاييد شده و طبق مقررات دانشـاه علوم يزشـكى ايـران مصـوب و اجـرا شـده اسـت. در گحروه

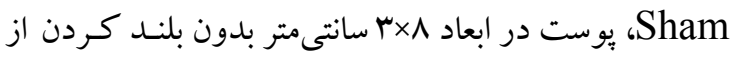
بستر خود برش داده شد. در گروه فـلابٍ، بـس از ايجـاد دو برش موازى، آنها به صورت متناوب متصل شده و يوست از

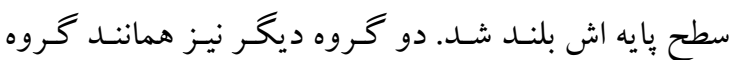
فلابٌ، جراحى فلاب شدند و سِّ با كيموفنول مطـابق دوز هاى كفته شده بـه مـــت يـك هفتـه، درمـان شـدند. قبـل از

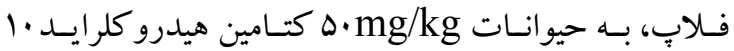

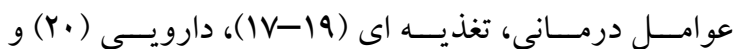
كونـاكونى هـاى زنتيكى، بـر روى بسـيارى از مكانيسمهــا، حالات فيزيوياتولوزيكك و ياتوبيولوزى سندرومها و سرطانهاى شايع انسانى موثر هستند (YY-YY). بين انواع مختلفى از عوامل درمانى، آنهايى كـهـ از محصـولات طبيعى و گياهـان مشتق شده اند بهتر هستند. بررسىهاى مختلفـى بـراى بهبـود وضعيت فلابِ هاى يوستى و همجينين ضايعات يوستى نظيـر بثورات جلدى(Y),YG) و يا زخم (YV) صورت كرفته اسـت كه مىتوان به استفاده از داروهايى مانند نيترو كليسيرين (Y^)

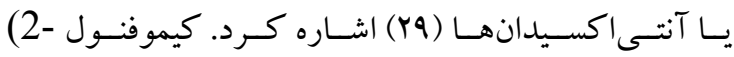
methyl-5-isopropylphenol) شـيميايى ${ }^{2} \mathrm{C}_{6} \mathrm{H}_{3} \mathrm{CH}_{3}(\mathrm{OH})\left(\mathrm{C}_{3} \mathrm{H}_{7}\right.$ فنـول داراى يكك عامل تـرين اسـت و از عصـاره روغنسى برخسى گياهـان

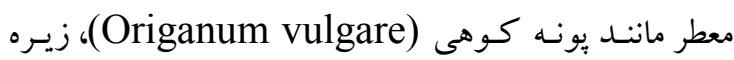

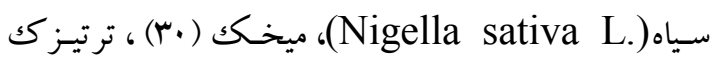
(Origanum (rآ)، مرزنجوش)(Lepidium flavum) majorana) مطالعات، برخى از خواص بيولوزيكى و دارويسى كيموفنسول مانند خاصيت آنتسى اكسيدانى (سM)، ضـد التهابى (هس, (MY)،

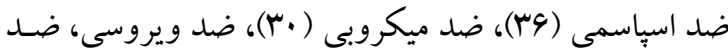
قارجى (TV) و ضد انعقادى را تاييد كرده اند (rN). مطالعهاى نشان داده است كه در يكك مدل بيمـارى بوسـتى، اسانس قيونه كوهى (OEO) بـه ميـزان قابـل تـوجهى سـطح برخى از بيوماركرهاى التهابى مانتـد MCAM-1 MCP-1، و ا كـاهش داده I-TAC، IP-10، VCAM-1، است (Y)). همجنين كيموفنول نقش مهمى در محدود كردن سـرعت آنـزيم سيكلو اكسـيزناز -r ب (COX-2)، عامـل بيوسـنتز يروسـتا گلاندينهــاى مـوثر در التهـاب و درد دارد

مطالعات متعددى درباره تاثير ايسكمى -ربرفيـون در بافـت-

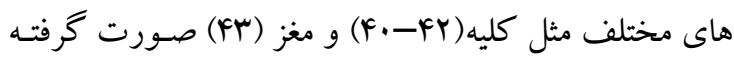

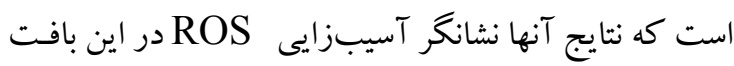
ها بـوده اسـت. در برخسى مـوارد اسـتفاده از نـانومواد آنتى - 
شـدند و در يكك حمـام يـخ تـا • ا درصـد (V / V) رقيتق

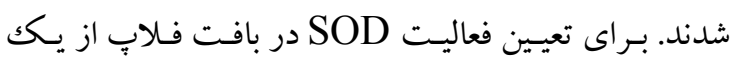

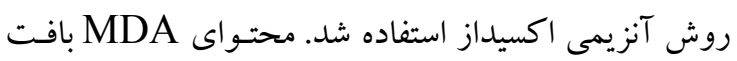

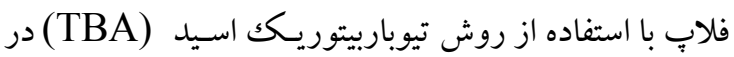

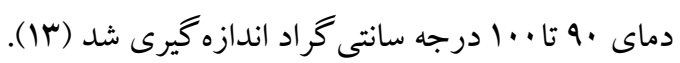
روش آمارى GraphPad تمام تجزيه و تحليل ها با استفاده از نرم افزار Prism 6 و آناليز يـس آزمـون (Tukey test) بـراى (ANOVA)

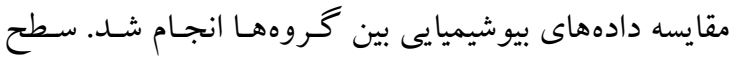
معنى دارى آمارى ه•/• P در نظر خرفته شد.

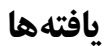

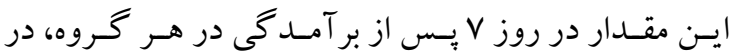
نمودار انشان داده شدهاند. بلند كردن فلاٍ منجر به كاهش بـ بـ ميزان بقاء به صورت شـديدى ( P > P) در مقابـل گرووه شد. تجويز كيموفنول بـا دوز پـايين باعث افزايش Sham

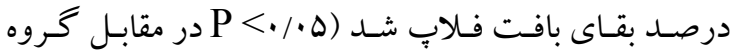
فلاب؛ نمودار (). در گروهى كـه تجويز كيموفنول بـا دوز

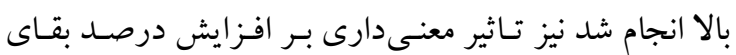

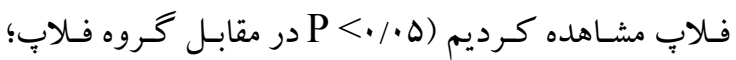
نمودار (). ما اختلاف معنىدارى در درصد بقاى فلابٍ بين

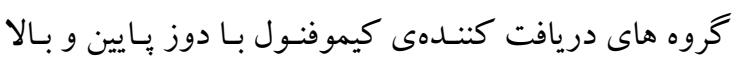
مشاهده نكرديم.
درصد، و Fmg/kg زايلازيـن r درصـد بـه صورت داخل صفاقى(i.p.) تزريق شد.

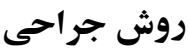
در مورد جراحسى فـلإ، ارتفـاع آن و انـدازه گيـرى ناحيـه نكروز و ناحيه سالم، بر اساس روش مكك فارلين عمل شـــه

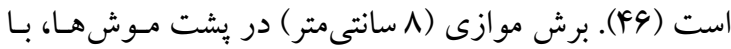
برش ץ سانتىمتر caudal incision متصل شد. بوست در منطقه به آرامى و با دقت، از بستر آن جدا شـد و يـك فيلم يلاستيكى استريل (روش استريل سازى: اتو كلاو) بين يوست بلند شده و فاشـياى آن قـرار كرفـت. دليل استفاده از فيلم جلو گيرى از ارتباط يوست فلاب با بستر بود كه بدين طريق جلوى ارتباط و ركَ زايـى از نـواحى تحتانى فلابٍ گرفتـه شود. بنابراين نقش فيلم استريل استفاده شده در فر آيند ترميم زخم، جلو گيرى از يرفيوزن زخم از ناحيهاى غيـر از يـديكل

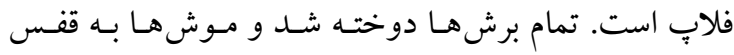

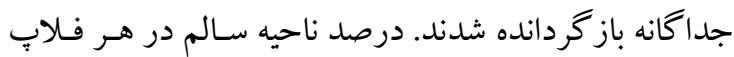
در روز هفتم پس از بالا بـردن فـلاٍ بـا تقسيم طول ناحيه

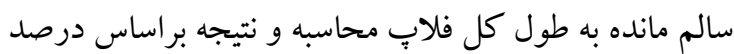
10·mg/kg محاسبه شد. در روز هفتم بـه مـوشهـا ميزان

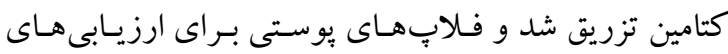
بيوشيميايى جمع آورى و ذخيره شدند. به تعداد ينج نمونه بافتى (ץ × × ميلىمتر) از هـر فـلاٍ تهيـه شده و يس از تعيين وزن، در بافر تريس اتيلن دى آمسين اتر

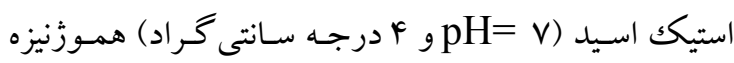

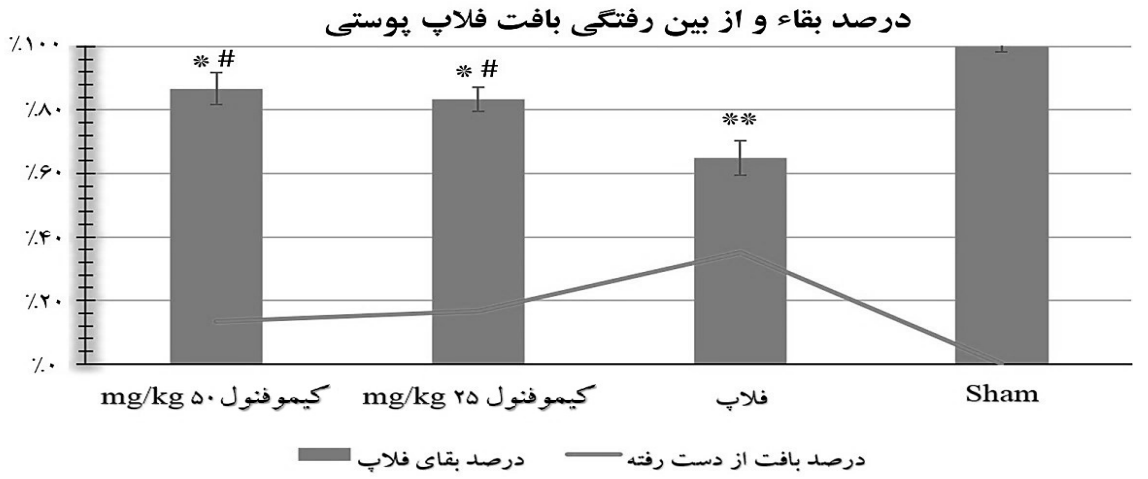

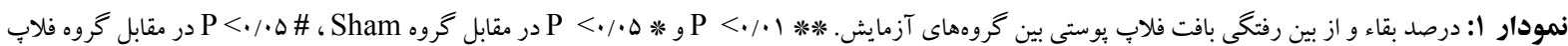


بيشترين تقرب را دارد و شيفت منحنى به سمت اين دو گروه

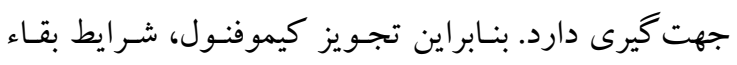
بافـت را بـه سـمت حسـداكثر بهـــودى سـوق داده اسـتـ.

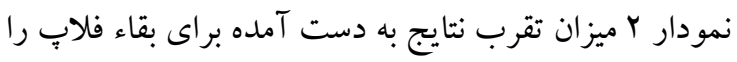

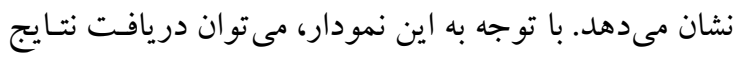

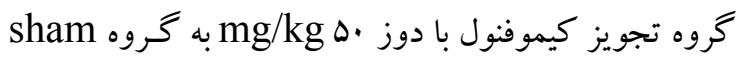

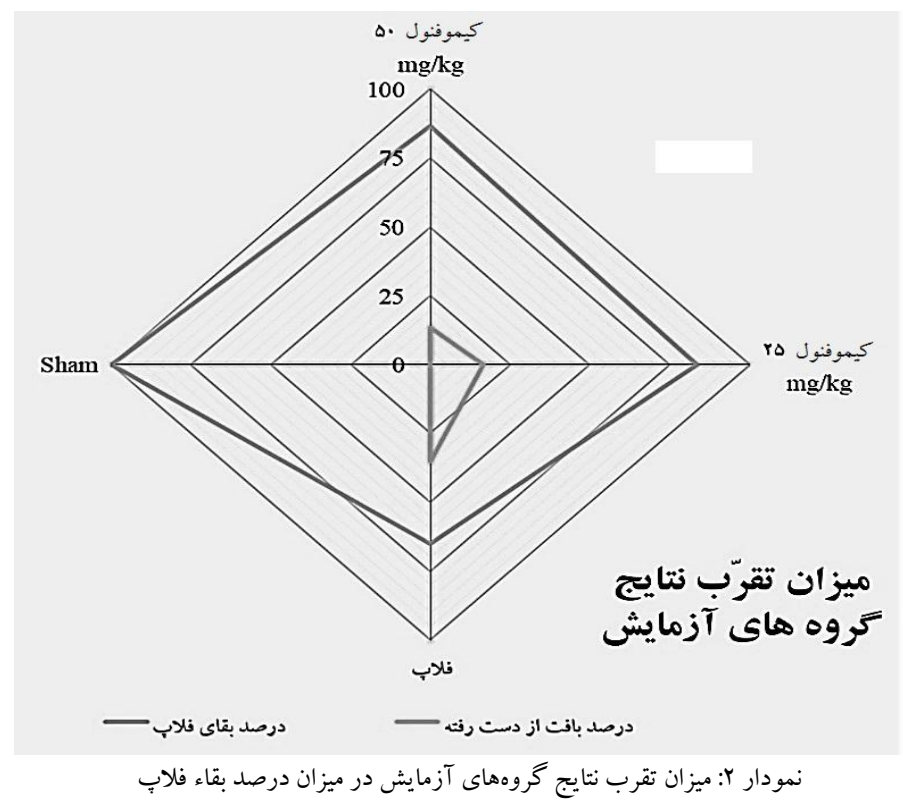

(نمودار ب) افزايش بيدا كـرد(1 (P P). تجـويز كيموفنـول ير اكسيداسيون ليييدى و متابوليتهاى حاصل از آن به عنوان با دوز يايين به طور قابـل تـوجهى منجـر بـهـ كـاهش مقــادير شـاخص اسـترس اكسـيداتيو مهمـى تلقى مسىشـوند كـه در MDA نمونههاى فلابٍ بر اساس محتـواى MDA در بافـت تعيـين

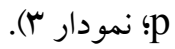
شده است. هفت روز يس از ايجـاد فـلابِ مشـاهده شـد كـه محتــواى Sham

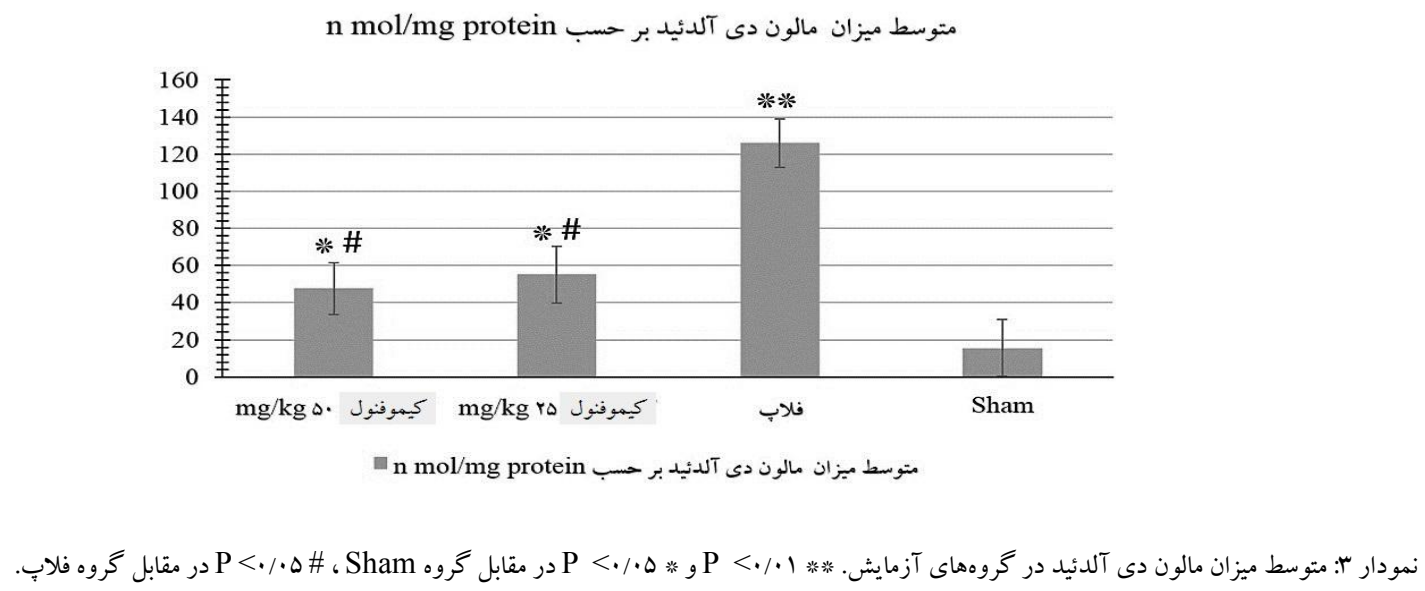


كيـرى دارد كـهـ نشـان دهنــدهى بيشـترين ميـزان آسـيب اكسيداتيو است. در مقابل منحنىى، مقـدار بسيار نـاجيزى در

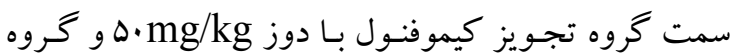
دارد، بنـابراين تجـويز كيموفنـول، شـرايط اسـترس اكسيداتيو را بـه سـمت حـداكثر بهبودى سـوق داده استـ.

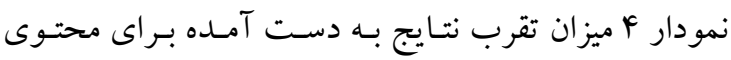

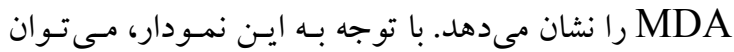

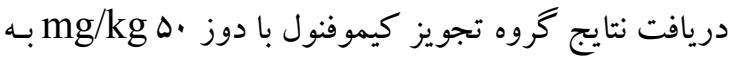

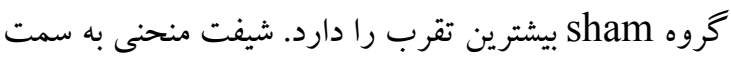

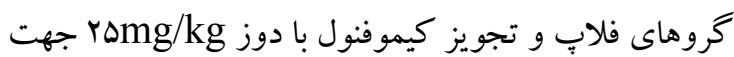

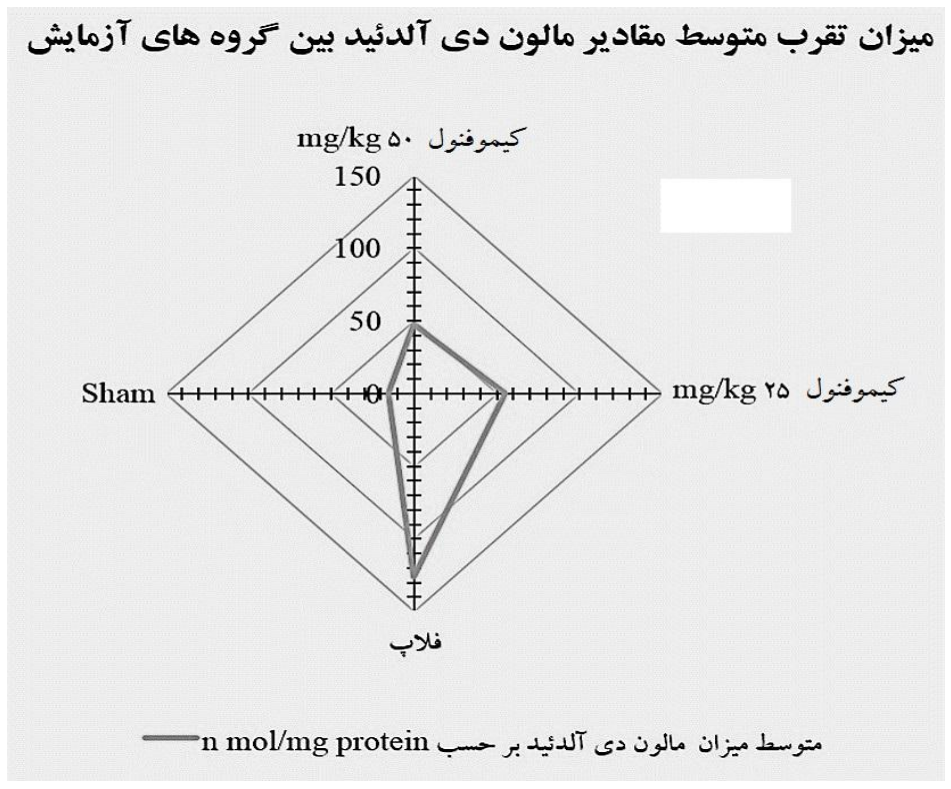

نمودار ٪: ميزان تقرب متوسط ميزان مالون دى آلدئيد در كروههاى آزمايش

ه). بـيش درمـان بـا كيموفنـول بـه طـور معنسى دارى فعاليـت

فعاليـت SOD بـه عنــوان نشـان دهنــده ى ظرفيـت آنتسى

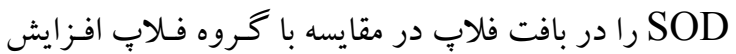

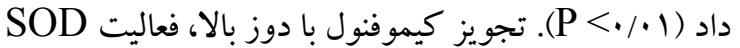

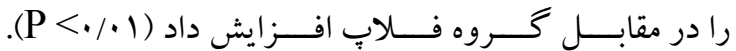

اكسيداني بافت فـلابِ مـورد ارزيابى قرار گرفـت. فعاليـت يكك هفته پِ از ايجاد مدل فلاب به طور معنىدارى SOD

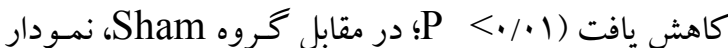

Uيزان فعاليت سوير اكسيد ديسموتاز بر حسب U/mg protein

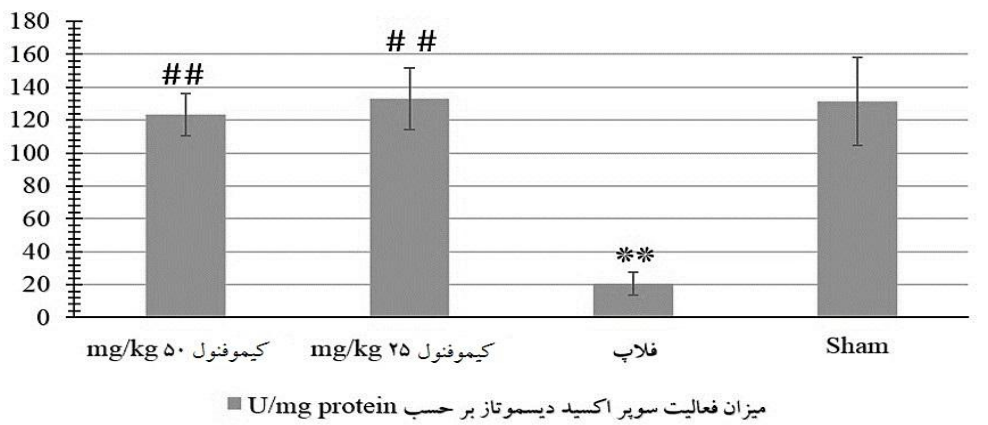

نمودار ه: ميزان فعاليت سويراكسيد ديسمو تاز در گروههاى آزمايش. 
شيفت منحنى به سمت گروههاى فلاب و تجويز كيموفنسول

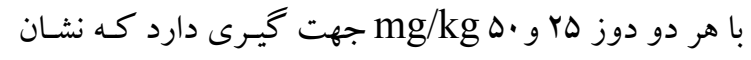

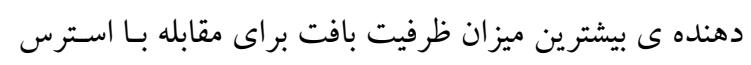

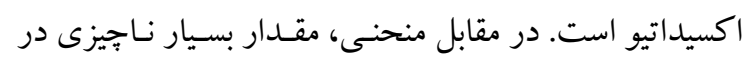

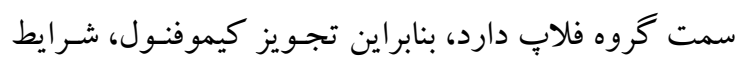

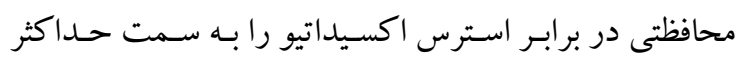
بهبودى سوق داده است.
ما اختلاف معنىدارى در محتواى MDA و فعاليـ SOD در بافتهاى فلاب تهيه شده از خروههاى تجويز كيموفنسول با دوز هاى مختلف مشاهده نكرديم.

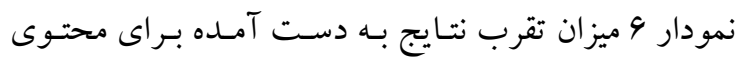

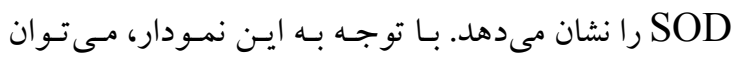

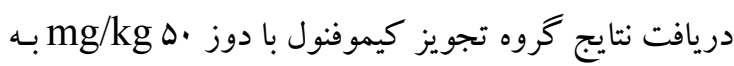

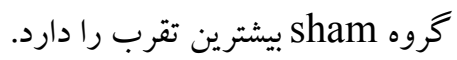

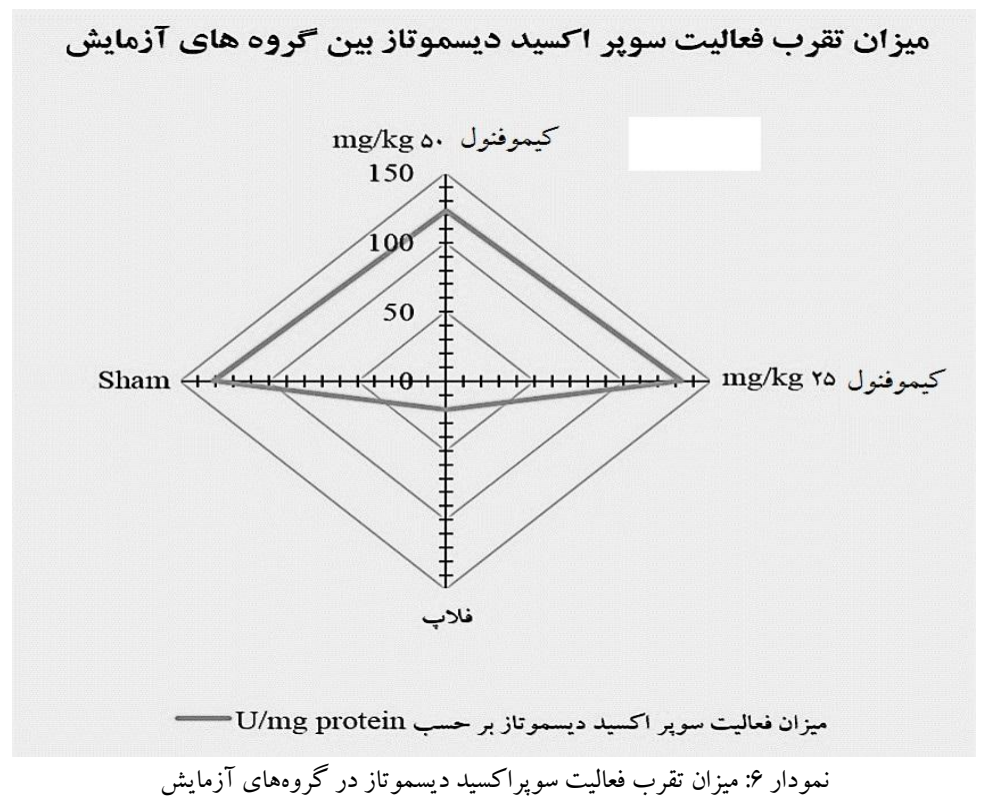

همجينين مطالعهى فوق نشان داد كيموفنول تاثير بارزى بر ادم

كوش ناشى از فعال كننده هِلاسمينوزن بافتى (tPA)و اسيد آراشيدونيك داشته است. در همين مطالعه تجويز خـوراكى كيموفنول براى fl روز متوالى نشان دهنده بهبود زخم معده مزمن ناشى از اسيد استيكك بوده است. نتايج مطالعه فوق بيان

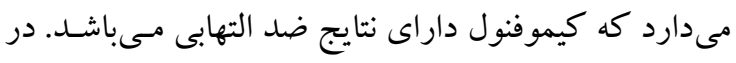

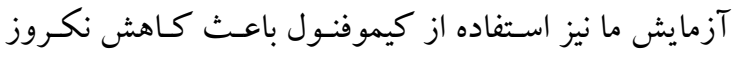

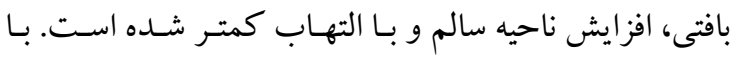

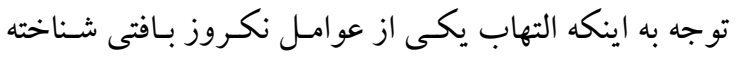

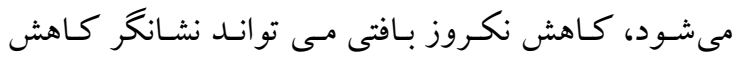

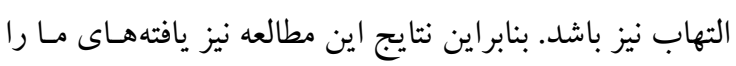
تاييد مى كند. ما در اين مطالعه براى اولين بار اثرات كيموفنـول بـر درصـد

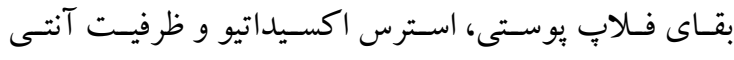
اكسيدانى بافت فلاٍ را بررسى كرديم كه نتايج نشان دهنده

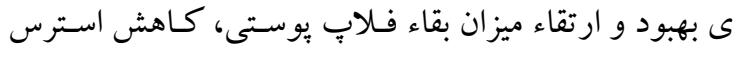
اكسيداتيو و افززيش ظرفيـت آنتى اكسيدانى بافـت فـلابِ در يكك مطالعه (Yr) كه تاثير كيموفنول بـر التهاب و زخـم مورد آزمايش قرار گرفته است كه بيشترين تـاثير كيموفنول بر ادم به وجود آمده با هيستامين و دكسترين در ناحيه دست

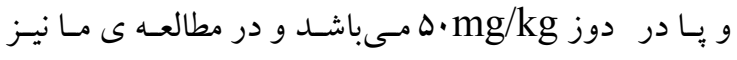

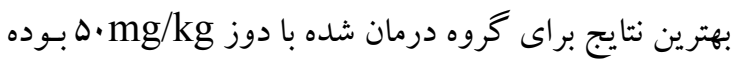

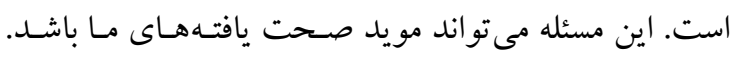


از يلى ساكاريد است- نشان دهند و نشان دادند كه دوزهاى

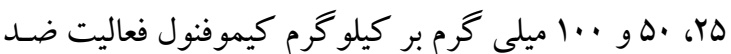

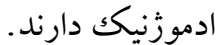
مطالعه اي ديخـر (FN) در مـورد اثر احتمـالى كيموفنول بـر

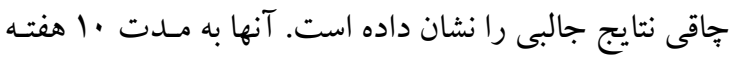

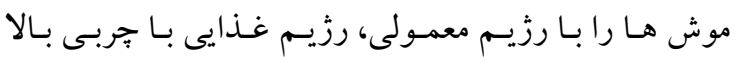

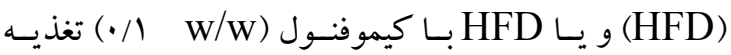
كردند. تاثير كاهشى كيموفنسول را بـر وزن بـدن، بــد جربسى

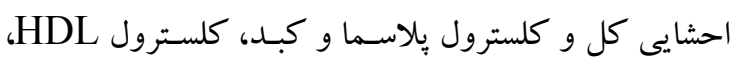

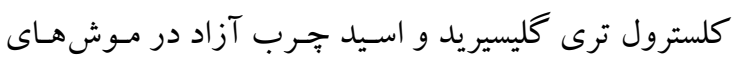

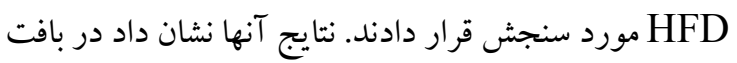
جربى احشايى، كيموفنول بيان زنهاى مرتبط با توليد خربى

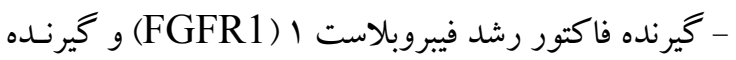

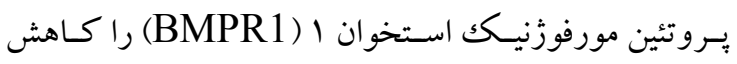

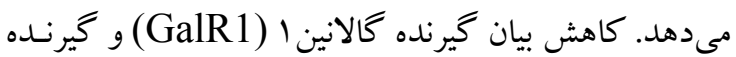

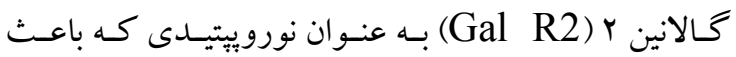
افزايش رزيم غذايى غنى از جربى مىشود، مشاهده مى شود.

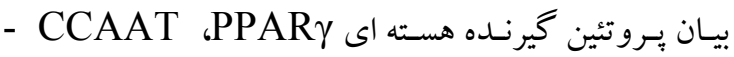
(C- بيروتئين اتصال دهنـده تقويـت كنـــCoactivator

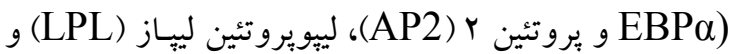
لِيتين هدف آنها كاهش مىيابد و در نتيجه توليد جربى ناشى از تغذيه با جربى بالا در رزيم غذايى توسط كيموفنول مهار مىشود. با اين حال، كيموفنول هيج تأثيرى بر تنظيم ترموزنز

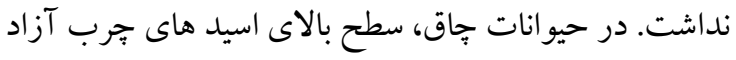
كزارش شده است و اين به دليل انتشار آنها يا از بافت جربى التهي

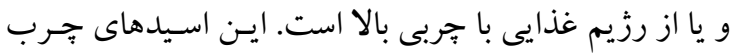

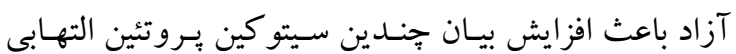
مانند نكروز تومور آلفا (TNF-

$$
\text { و اينترلو كين } 9 \text { (IL-6) مى شودد. }
$$

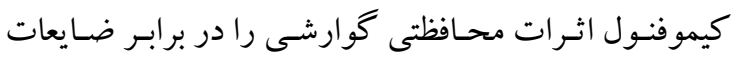

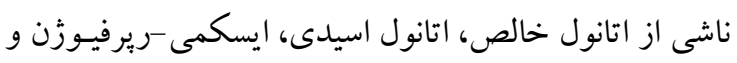

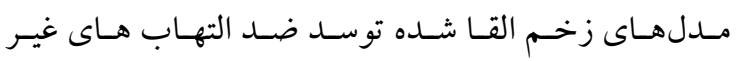

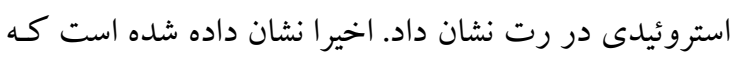

همجنين در مطالعه اى (س/) كـه تـاثيرات آنتى اكسيدانى و ضد انعقادى كيموفنول مورد بررسى قرار گرفته است، اندازه گيرى گونههاى واكنش گر باربيتوريكك اسيد (TRAP) و تيوباربيتوريكك اسيد(TAR)، ظرفيت آنتى اكسيدان قوى كيموفنول را درغلظتهاى مختلف نشان مى دهد و يافته هـا

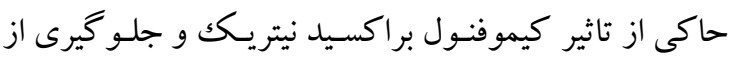

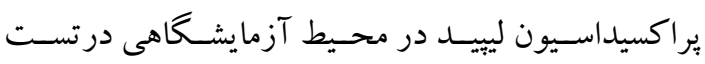
TBARS

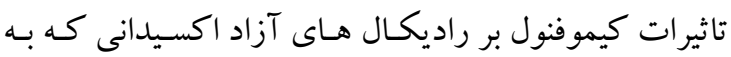
عنوان عامل تخريبى فلاب هاى بوستى شناخته مىشوند بـى

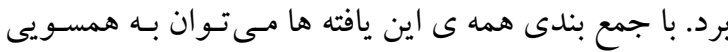

اين مطالعات با نتايج به دست آمده از تحقيق ما يـى برد.

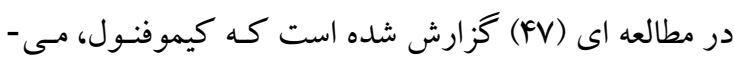

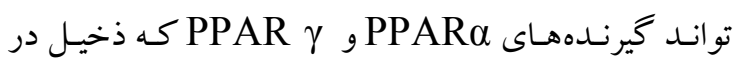
فر آيندهاى تنظيم كننده بيان زن ها هستند را فعـال كند كه.

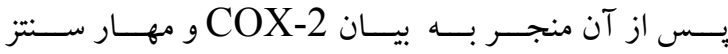
يروستا كلاندين در طول التهاب مىشود. علاوه بر اين، عمل العل

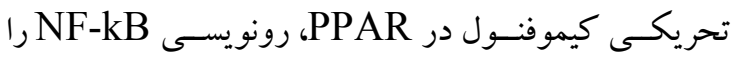
مهار مى كند كه به نوبه ى خود اين امر باعث كاهش سطح

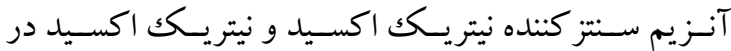
ماكروفازها مىشود كه در جهت اثر ضـد دردى كيموفنـول است. همجِنين اثر كيموفنول را با استفاده از جنــدين مـدل از اخستلالات hypernociceptive يـا بـيش دردزايسى يـا التهاب در موش هـا در ماكروفازهـاى مـوش هـاى تحريـك

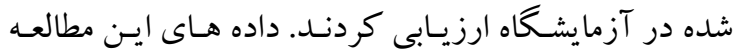

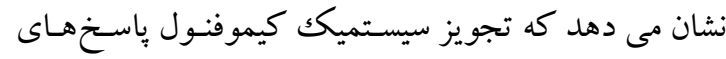

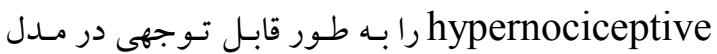
هاى حاد بيمارىهاى التهابى كـاهش مى دهدكه عـلاوه بـر اين، دادههايى مبنى بر احتمال دخالت در مسير التهابى نيز

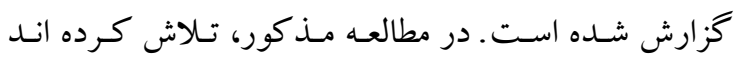
اثرات كيموفنول را در مرحله اول التهاب ينجهى مـوش كـه

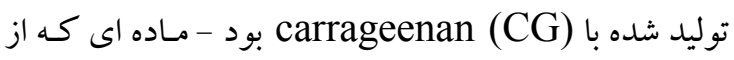
جلبكك دريايى قرمز و بنفش استخراج شده و شـامل تركيبى 


\section{نتيجه كيرى}

سوير اكسيد ديسمو تاز به عنوان بخشى از سيستم دفاع اوليـه

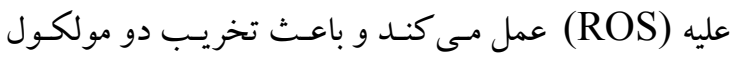
آنيون سوير اكسيد به يراكسيد هيدروزن و اكسيزن مولكولى هيلى

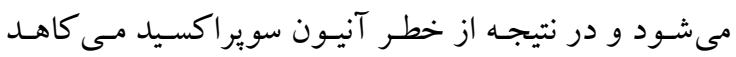
(DF-OV)

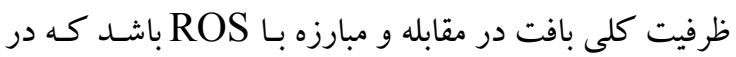
آزمايش ما، كيموفنول SOD را افزايش داده اسـت. مـالون

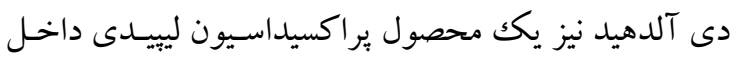
سلولى است كه بـه علـت اثرات سـمى راديكـال هـاى آزاد

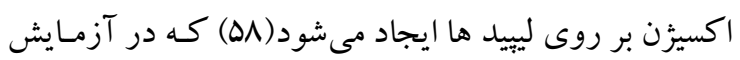

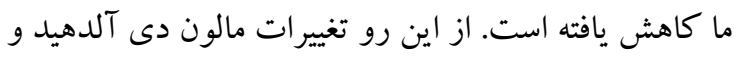

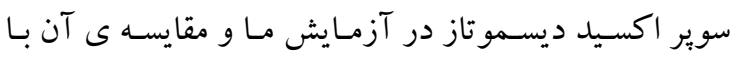

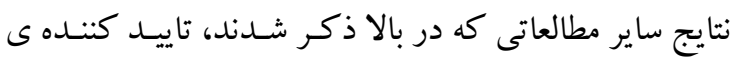
هم هستند. در نهايت با توجه به نتايجى كـه بـه دسـت آورديسم، تجـويز

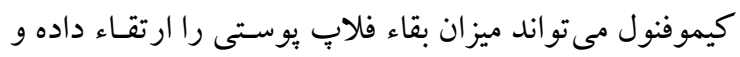

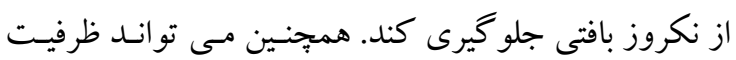

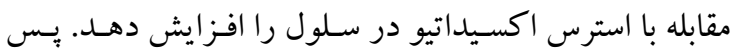

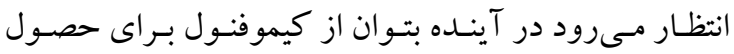
نتيجه اثر بخش تر در جراحى هـاى فلاٍ استفاده كرد. البته بقيه جوانب اثر اين ماده بر روى فلاٍ هاى بوستى هنوز

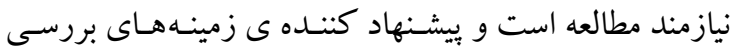
بيشتر براى آينده مىباشد.

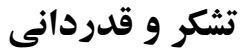

نويسندكان از شركت جـان ويشار جهت تـامين تجهيزات لازم براى آزمايشات و مركز تحقيقات فيزيولوزى دانشكده يز شكى دانشكاه علوم بزشكى ايران تشكر و قـدردانى مسى -
اثر ضدعفونى كيموفنول توسط بروستا كالاندينهاى اندوزن، افزايش توليـد مو كوس، بـاز كردن كانـال KATP، فعـال سازى سنتز نيتريك اكسيد NO N خو اص آنتى اكسيدانى آن واسطه گرى مىشود (Fq).

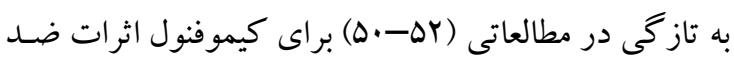

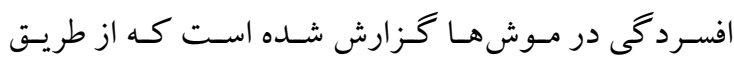
مدولاسيون انتقال و و و سيستم دويامينرزيـك رخ مىدهد كه مى تواند از سد خونى -مغزي بـه دليل وزن

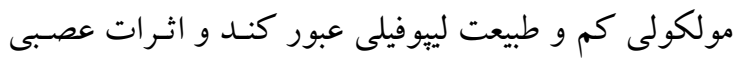

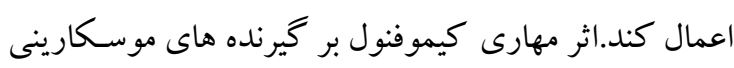

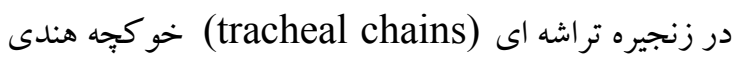

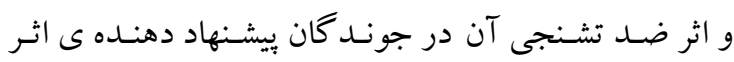
محافظتى كيموفنول بر نورون ها مىباشد.

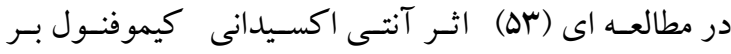

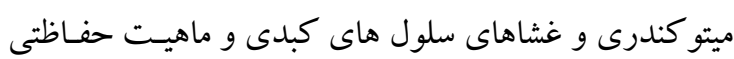

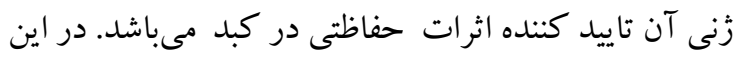

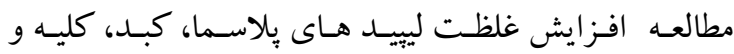

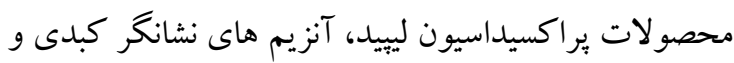

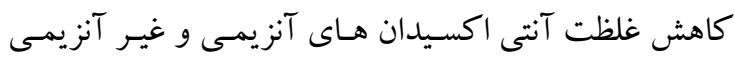

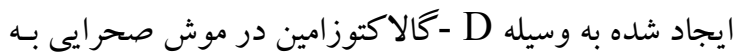
وسـيله كيموفنـول (romg/kg bw) بـه حالـت طبيعى باز گشـته و ايـن اثـر قابـل مقايسـهـ بـا ســيليمارين اسـتاندارد -D اسـت عـلاوه بــر ايسن، كـاهش (romg/kg bw) كالاكتوزامين در آنزيم هاى ميتو كندرى و آسيب DNA توسط كيموفنول بازسازى و كنترل شده است. 


\section{References}

1. Dölen UC, Sungur N, Koca G, Ertunç O, Bağcı Bosi AT, Koçer U, et al. The Vasodilator effect of a cream containing $10 \%$ menthol and $15 \%$ methyl salicylate on random-pattern skin flaps in rats. Arch Plast Surg 2015;42:695-703.

2. Brown DL, Penington AJ. Murine skin flap survival may not be affected by underlying fat viability. J Plast Reconstr Aesthet Surg 2007;60:294-9.

3. Zhang T, Gong W, Li Z, Yang S, Zhang K, Yin D, et al. Efficacy of hyperbaric oxygen on survival of random pattern skin flap in diabetic rats. Undersea Hyperb Med 2007;34:335-9.

4. Yeoh MS, Kim DD, Ghali GE. Fluorescence angiography in the assessment of flap perfusion and vitality. Oral Maxillofac Surg Clin North Am 2013;25:61-6, vi.

5. Bagdas D, Cam Etoz B, Inan Ozturkoglu S, Cinkilic N, Ozyigit MO, Gul Z et al. Effects of systemic chlorogenic acid on random-pattern dorsal skin flap survival in diabetic rats. Biol Pharm Bull 2014;37:361-70.

6. Holm C, Dornseifer U, Sturtz G, Ninkovic M. Sensitivity and specificity of ICG angiography in free flap reexploration. J Reconstr Microsurg 2010;26:311-6.

7. Moran SL, Nava G, Behnam AB, Serletti JM. An outcome analysis comparing the thoracodorsal and internal mammary vessels as recipient sites for microvascular breast reconstruction: A prospective study of 100 patients. Plast Reconstr Surg 2003;111:1876-82.

8. Nahabedian MY, Momen B, Manson PN. Factors associated with anastomotic failure after microvascular reconstruction of the breast. Plast Reconstr Surg 2004;114:74-82.

9. Pazoki-Toroudi H, Ajami M, Babakoohi S, Khaki L, Habibey R, Akhiani M et al. Effects of diphencyprone on expression of $\mathrm{Bcl}-2$ protein in patients with alopecia areata. Immunopharmacol Immunotoxicol 2010;32:422-5.

10. Hengartner MO. The biochemistry of apoptosis. Nature 2000;407:770-6.

11. Fang FC. Antimicrobial actions of reactive oxygen species. MBio. 2011;2:pii: e001411.

12. Ajami M, Davoodi SH, Habibey R, Namazi N, Soleimani M, Pazoki-Toroudi H. Effect of DHA+EPA on oxidative stress and apoptosis induced by ischemia-reperfusion in rat kidneys. Fundam Clin Pharmacol 2013;27:593-602.

13. Habibey R, Ajami M, Ebrahimi SA, Hesami A, Babakoohi S, Pazoki-Toroudi H. Nitric oxide and renal protection in morphine-dependent rats. Free Radic Biol Med 2010;49:1109-18.

14. Pazoki-Toroudi H, Nilforoushzadeh MA, Ajami M, Jaffary F, Aboutaleb N, Nassiri-Kashani M, et al. Combination of azelaic acid 5\% and clindamycin $2 \%$ for the treatment of acne vulgaris. Cutan Ocul Toxicol 2011;30:286-91.

15. Ajami M, Eghtesadi S, Razaz JM, Kalantari N, Habibey R, Nilforoushzadeh MA, et al. Expression of Bcl-2 and Bax after hippocampal ischemia in DHA + EPA treated rats. Neurol Sci 2011;32:811-8.

16. Moseley R, Stewart JE, Stephens P, Waddington RJ, Thomas DW. Extracellular matrix metabolites as potential biomarkers of disease activity in wound fluid: Lessons learned from other inflammatory diseases?. Br J Dermatol 2004;150:401-13.

17. Toroudi HP, Rahgozar M, Bakhtiarian A, Djahanguiri B. Potassium channel modulators and indomethacin-induced gastric ulceration in rats. Scand J Gastroenterol 1999;34:962-6.

18. Amani H, Ajami M, Nasseri Maleki S, Pazoki-Toroudi H, Daglia M, Tsetegho Sokeng AJ, et al. Targeting signal transducers and activators of transcription (STAT) in human cancer by dietary polyphenolic antioxidants. Biochimie 2017;142:63-79. 
19. Shayanfar M, Vahid F, Faghfoori Z, Davoodi SH, Goodarzi R. The Association between index of nutritional quality (INQ) and glioma and evaluation of nutrient intakes of these patients: a case-control study. Nutr Cancer 2018;70:213-20.

20. Moradi-Joo M, Mohabbat-Bahar S, Heidari S, Davoodi SH, Gareh Sheyklo S, Akbari M-E. Metformin Versus Sulfonylurea in Breast Cancer Risk of Diabetic Patients: A Systematic Review and Meta-Analysis. Iran J Cancer Prev 2016;9:e5971.

21. Bani Mohammad M, Majdi Seghinsara A. Polycystic ovary syndrome (PCOS), diagnostic criteria, and AMH. Asian Pac J Cancer Prev 2017;18:17-21.

22. Majdi Seghinsara A, Banimohammad M. New facts about ovarian stem cells: the origin and the fate. International Journal of Women's Health and Reproduction Sciences 2018;6:127-33.

23. Vahid F, Shivappa N, Faghfoori Z, Khodabakhshi A, Zayeri F, Hebert JR, et al. Validation of a dietary inflammatory index (DII) and association with risk of gastric cancer: a case-control study. Asian Pac J Cancer Prev 2018;19:1471-7.

24. Vahid F, Shivappa N, Hatami M, Sadeghi M, Ameri F, Jamshidi Naeini Y, et al. Association between dietary inflammatory index (DII) and risk of breast cancer: a case-control study. Asian Pac J Cancer Prev 2018;19:1215-21.

25. Pazoki-Toroudi H, Nassiri-Kashani M, Tabatabaie H, Ajami M, Habibey R, Shizarpour M, et al. Combination of azelaic acid 5\% and erythromycin 2\% in the treatment of acne vulgaris. J Dermatolog Treat 2010;21:212-6.

26. Firooz A, Bouzari N, Mojtahed F, Pazoki-Toroudi H, Nassiri-Kashani M, Davoudi M, et al. Topical immunotherapy with diphencyprone in the treatment of extensive and/or long-lasting alopecia areata. J Eur Acad Dermatol Venereol 2005;19:393-4.

27. Tejada S, Manayi A, Daglia M, Nabavi SF, Sureda A, Hajheydari Z, et al. Wound healing effects of curcumin: a short review. Curr Pharm Biotechnol 2016;17:1002-7.

28. Sa JZd, Aguiar JLdA, Cruz AF, Schuler ARP, Lima JRAd, Marques OM. The effects of local nitroglycerin on the surgical delay procedure in prefabricated flaps by vascular implant in rats. Acta Cir Bras 2012;27:905-11.

29. Ciloglu NS, Zeytin K, Aker F. The effects of resveratrol on flap survival in diabetic rats. J Plast Surg Hand Surg 2014;48:234-7.

30. Ben Arfa A, Combes S, Preziosi-Belloy L, Gontard N, Chalier P. Antimicrobial activity of carvacrol related to its chemical structure. Lett Appl Microbiol 2006;43:149-54.

31. MohaMed ezzat abd el and Hack and Mayada Ragab Farag and Ruchi and Tiwari. Biological Effects and Modes of Action of Carvacrol in Animal and Poultry Production and Health-A Review. Advances in Animal and Veterinary Sciences 2015;3:73-84.

32. Silva FV, Guimaraes AG, Silva ERS, Sousa-Neto BP, Machado FDF, Quintans-Junior LJ, et al. Anti-inflammatory and anti-ulcer activities of carvacrol, a monoterpene present in the essential oil of oregano. J Med Food 2012;15:984-91.

33. Guimaraes AG, Oliveira GF, Melo MS, Cavalcanti SCH, Antoniolli AR, Bonjardim LR, et al. Bioassay-guided evaluation of antioxidant and antinociceptive activities of carvacrol. Basic Clin Pharmacol Toxicol 2010;107:949-57.

34. Hotta M, Nakata R, Katsukawa M, Hori K, Takahashi S, Inoue H. Carvacrol, a component of thyme oil, activates PPARalpha and gamma and suppresses COX-2 expression. J Lipid Res 2010;51:132-9.

35. Landa P, Kokoska L, Pribylova M, Vanek T, Marsik P. In vitro anti-inflammatory activity of carvacrol: Inhibitory effect on COX-2 catalyzed prostaglandin E(2) biosynthesis. Arch Pharm Res 2009;32:75-8. 
36. Astudillo A, Hong E, Bye R, Navarrete A. Antispasmodic activity of extracts and compounds of Acalypha phleoides Cav. Phytother Res 2004;18:102-6.

37. Gunal M, Heper A, Zaloglu N. The effects of topical carvacrol application on wound healing process in male rats. Pharmacognosy Journal 2014;6:10-3.

38. Enomoto S, Asano R, Iwahori Y, Narui T, Okada Y, Singab AN, et al. Hematological studies on black cumin oil from the seeds of Nigella sativa L. Biol Pharm Bull 2001;24:307-10.

39. Han X, Parker TL. Anti-inflammatory, tissue remodeling, immunomodulatory, and anticancer activities of oregano (Origanum vulgare) essential oil in a human skin disease model. Biochimie Open 2017;4:73-7.

40. Pazoki-Toroudi HR, Ajami M, Habibey R. Pre-medication and renal pre-conditioning: A role for alprazolam, atropine, morphine and promethazine. Fundam Clin Pharmacol 2010;24:189-98.

41. Mehrjerdi FZ, Aboutaleb N, Pazoki-Toroudi H, Soleimani M, Ajami M, Khaksari M et al. The protective effect of remote renal preconditioning against hippocampal ischemia reperfusion injury: role of KATP channels. J Mol Neurosci 2015;57:554-60.

42. Javedan G, Shidfar F, Davoodi SH, Ajami M, Gorjipour F, Sureda A et al. Conjugated linoleic acid rat pretreatment reduces renal damage in ischemia/reperfusion injury: unraveling antiapoptotic mechanisms and regulation of phosphorylated mammalian target of rapamycin. Mol Nutr Food Res 2016;60:2665-77.

43. Arabian M, Aboutaleb N, Soleimani M, Mehrjerdi FZ, Ajami M, Pazoki-Toroudi H. Role of morphine preconditioning and nitric oxide following brain ischemia reperfusion injury in mice. Iran $\mathrm{J}$ Basic Med Sci 2015;18:14-21.

44. Zarch AV, Toroudi HP, Soleimani M, Bakhtiarian A, Katebi M, Djahanguiri B. Neuroprotective effects of diazoxide and its antagonism by glibenclamide in pyramidal neurons of rat hippocampus subjected to ischemia-reperfusion-induced injury. Int J Neurosci 2009;119:1346-61.

45. Chen W, Xu B, Xiao A, Liu L, Fang X, Liu R, et al. TRPM7 inhibitor carvacrol protects brain from neonatal hypoxic-ischemic injury. Molecular Brain 2015;8:11.

46. Mcfarlane RM, Deyoung G, Henry RA. The design of a pedicle flap in the rat to study necrosis and its prevention. Plast Reconstr Surg 1965;35:177-82.

47. Guimarães AG, Xavier MA, Santana MT de, Camargo EA, Santos CA, Brito FA, et al. Carvacrol attenuates mechanical hypernociception and inflammatory response. Naunyn Schmiedebergs Arch Pharmacol 2012;385:253-63.

48. Cho S, Choi Y, Park S, Park T. Carvacrol prevents diet-induced obesity by modulating gene expressions involved in adipogenesis and inflammation in mice fed with high-fat diet. J Nutr Biochem 2012;23:192-201.

49. Earley S, Gonzales AL, Garcia ZI. A dietary agonist of transient receptor potential cation channel V3 elicits endothelium-dependent vasodilation. Mol Pharmacol 2010;77:612-20.

50. Habibey R, Pazoki-Toroudi H. Morphine dependence protects rat kidney against ischaemiareperfusion injury. Clin Exp Pharmacol Physiol 2008;35:1209-14.

51. Melo FHC, Moura BA, Sousa DP de, Vasconcelos SMM de, Macedo DS, Fonteles MMdF, et al. Antidepressant-like effect of carvacrol (5-Isopropyl-2-methylphenol) in mice: Involvement of dopaminergic system. Fundam Clin Pharmacol 2011;25:362-7.

52. Trabace L, Zotti M, Morgese MG, Tucci P, Colaianna M, Schiavone S, et al. Estrous cycle affects the neurochemical and neurobehavioral profile of carvacrol-treated female rats. Toxicol Appl Pharmacol 2011;255:169-75.

53. Aristatile B, Al-Numair KS, Veeramani C, Pugalendi KV. Antihyperlipidemic effect of carvacrol on D-galactosamine-induced hepatotoxic rats. J Basic Clin Physiol Pharmacol 2009;20:15-27.

54. Zhu W-H, Leng X-S, Zhu J-Y. Effect of Shenfu injection on ischemia-reperfusion injury of rat liver graft. Hepatobiliary Pancreat Dis Int 2006;5:205-9. 
55. Banimohammad M, Farrokhi M, Varshoei B, Ayatollahi SA. Effects of saffron oral gavage on protection of skin flaps against tissue necrosis and oxidative stress in rats. Koomesh 2019;21:347-53. [In Persian]

56. Banimohammad M, Javdan G, Samavat Ekbatan S, Safe M, Hajheydari Z. Protective effect of oral extract of stevia rebaudiana on skin flap survival in male rats. J Mazand Univ Med Sci 2018;28:1-9. [In Persian]

57. Razaz JM, Ebadi Fard Fzar Aa, Naziri M, Banimohammad M, Majdi Seghinsara A, Javdan G. Effects of oral gavage treatment of Eupatilin on protection of skin flaps in rats. Koomesh 2019;21:318-23. [In Persian]

58. Dingsheng L, Zengbing L, Dong H. Favorable effects of progesterone on skin random flap survival in rats. Iran J Basic Med Sci 2016;19:1166-70. 